\title{
SLOVENIJA: SPREMINJANJE IN RAZNOLIKOST NA MAJHNEM PROSTORU
}

\author{
Volker Albrecht in Vladimir Drozg (ur.): Slowenien: Transformationen und \\ kleinräumige Vielfalt. Zbirka Natur-Raum-Gesellschaft 5, 344 str. Institut für \\ Humangeographie. Frankfurt am Main 2008.
}

Ni veliko priložnosti, ko v tujini izide povsem izvirno zasnovana geografska monografija o Sloveniji, zato imajo takšni dogodki še poseben pomen, tako za celotno državo kot tudi za našo geografsko stroko. V začetku lanskega poletja je prišla med nemške bralce nova obsežna monografija o geografskih značilnostih naše države, ki ji daje posebno težo še dejstvo, da so pri njenem nastajanju poprijeli geografi z vseh treh slovenskih geografskih oddelkov in Geografskega inštituta A. Melika ZRC SAZU. Levji delež dela na projektu sta seveda opravila oba urednika: VOLKER ALBRECHT s frankfurtskega Inštituta za humano geografijo, ki je poleg finančnih sredstev za tiskanje knjige skupaj s sourednikom poskrbel še za uravnotežen, nemškemu bralstvu prirejen koncept, in VLADIMIR DROZG z mariborske Filozofske fakultete, kateremu smo med drugim dolžni zahvalo za prizadevno organizacijsko delo in usklajevanje velikega števila zelo različno usmerjenih avtorjev.

Knjiga prinaša 18 prispevkov 16 avtorjev, enega nemškega (V. Albrecht, Uvod) in 15 slovenskih. Poglavja niso klasično regionalnogeografsko zasnovana, ampak so avtorji v skladu s konceptom, ki ga je v uvodnem poglavju predstavil VOLKER ALBRECHT, poskušali čim bolj objektivno predstaviti obstoječo geografsko stvarnost sodobne Slovenije ter okoliščine in procese, ki so privedli do takšnega stanja. V tovrstnih delih sicer vedno ‘še manjkajo' določene vsebine oziroma poglavja, ki bi jih bilo tudi potrebno obdelati, vendar neusmiljeno postavljeni roki in visoke zahteve obeh urednikov ter nemških recenzentov niso dopuščali veliko možnosti poljubnega podaljševanja rokov.

Pouvodnem prispevku Volkerja Albrechta, v katerem predstavi koncept knjige in nekatere svoje poglede na geografijo nasploh in na Slovenijo, so nanizani prispevki slovenskih avtorjev: poglavje Slovenija v času in prostoru (ANTON GOSAR) predstavlja ključne geografske determinante Slovenije, ki v veliki meri določajo njen zgodovinski razvoj, vključevanje v evropske integracije in tudi odnose s sosednjimi državami. Poglavje Relief in pokrajine (KAREL NATEK) obravnava fizičnogeografske osnove pokrajinske pestrosti Slovenije ter odvisnost drugih pokrajinskih sestavin od izoblikovanosti površja, tako z vidika možnosti (naravni viri) kot omejitev. V naslednjem poglavju Slovenske pokrajine (KAREL NATEK) so na kratko predstavljeni pokrajinskoekološka členitev Slovenije na pet makroregij in njihove osnovne značilnosti, nato pa sledita dve klimatogeografski poglavji: Prostorska raznolikost podnebja in rastja (DARKO OGRIN) pojasnjuje izjemno pokrajinsko pestrost Slovenije z vidika prehodnosti iz mediteranskega $\mathrm{v}$ celinsko podnebje, bogastvo tipov rastja pa poleg klimatske raznolikosti določajo še drobna reliefna razčlenjenost in hitro menjavanje drugih geografskih danosti na zelo kratke razdalje. V poglavju Spreminjanje podnebja v Sloveniji (IGOR ŽIBERNA) je najprej predstavljen prispevek Slovenije k emisijam toplogrednih plinov, nato konkretni učinki globalnega segrevanja ozračja v Sloveniji (spreminjanje količine in razporeditve padavin, naraščanje sušnosti, snežna odeja). 
Naslednji dve poglavji se ukvarjata s problematiko varstva okolja: poglavje Slovenija in trajnostni razvoj (METKA ŠPES) nudi vpogled v preteklo in sedanje stanje na področju obremenjevanja okolja in predstavlja nekatere pozitivne trende, ki kažejo na postopno uveljavljanje paradigme trajnostnega razvoja (zmanjšanje emisij $\mathrm{SO}_{2}$, gradnja komunalnih čistilnih naprav, izkoriščanje lesne biomase za pridobivanje energije, ekološko kmetijstvo, ekološke šole). Sledi poglavje Zavarovana območja in trajnostni regionalni razvoj Slovenije (DUŠAN PLUT), v katerem avtor vrednoti različne vrste zavarovanih območij z vidika prednosti in omejitev nadaljnjega regionalnega razvoja. Pri skoraj polovičnem deležu tako ali drugače zavarovanih območij je nujno, da regionalni razvoj in regionalna politika upoštevata varstvo naravne in kulturne dediščine ter vzpostavljata ustrezne pogoje za uveljavitev trajnostnega razvoja ter gospodarsko delovanje lokalnega prebivalstva na teh območjih.

Sledi sklop treh poglavij o prebivalstveni problematiki Slovenije: v poglavju Prebivalstvo med podeželskim načinom življenja in urbanim razvojem (STANE PELC) prikazuje avtor poglavitne demogeografske spremembe $\mathrm{v}$ času in prostoru ter njihov odraz v sodobni pokrajini (narodnostna struktura, staranje prebivalstva, poselitveni vzorec, dnevne migracije idr.). Poglavje Slovenci kot narodna manjšina v sosednjih državah (JERNEJ ZUPANČIČ) predstavlja zgodovinske razloge za obstoj skupnosti naših rojakov v sosednjih državah, velike spremembe v njihovem položaju po nastanku neodvisne Slovenije ter različne stopnje njihove zakonske in dejanske zaščite. Slovenska pot iz agrarne družbe v postindustrijsko državo (LUČKA LORBER) je prispevek o velikih družbenih in prostorskih spremembah, ki jih je Slovenija doživela $\mathrm{v}$ zadnjih sto letih ob prehodih iz klasične agrarne $\mathrm{v}$ socialistično in nato $\mathrm{v}$ sodobno, na tržnem gospodarstvu temelječo družbeno skupnost, med drugim velike spremembe $\mathrm{v}$ zaposlitveni strukturi, razporeditvi delovnih mest, razlikah med regijami ipd.

V naslednjem sklopu poglavij sta $\mathrm{v}$ ospredju regionalno planiranje in regionalna politika: poglavje Ljubljanska regija kot gospodarsko središče Slovenije (ANDREJ ČERNE) predstavlja Ljubljano kot nesporno središče celotne države. Prikazane so velike strukturne spremembe $v$ mestnem jedru in primestnih območjih ter v migracijskih tokovih, s poudarkom na spremembah, povezanih s hitro uveljavitvijo Ljubljane kot glavnega mesta samostojne slovenske države. Tudi poglavje Turizem v Sloveniji (UROŠ HORVAT) obravnava Ljubljano kot pomembno turistično destinacijo, poseben poudarek pa je na velikem turističnem potencialu in možnostih razvoja različnih vej turizma, povezanih z drobno pokrajinsko raznolikostjo in raznoliko turistično ponudbo. Poglavje Regionalna politika in regionalni razvoj v Sloveniji (MARJAN RAVBAR) preverja veljavnost koncepta zagotavljanja enake kvalitete življenja za vse prebivalce, pri čemer je ključno spodbujanje razvoja policentričnega urbanega sistema. Zastavljeni koncept seveda ni bil v celoti uresničen, zato avtor posebej obravnava problematiko spodbujanja razvoja strukturno šibkih območij ter ključne spremembe in probleme dosedanjega in prihodnjega regionalnega razvoja.

Sourednik monografije (VLADIMIR DROZG) je prispeval dvoje poglavij o naseljih: v prvem (Podeželska naselja med raznolikostjo in transformacijo) sooči tradicionalno strukturo podeželskih naselij, tesno povezano $\mathrm{z}$ drobno pokrajinsko raznolikostjo ter različnimi fizičnoin družbenogeografskimi dejavniki, z modernimi in postmodernimi trendi njihovega preoblikovanja, ki se kažejo tako v tipih hiš kot v spreminjanju podobe in funkcije naselij. Drugi 
prispevek (Slovenska mesta) predstavlja glavne razvojne faze slovenskih mest, s poudarkom na njihovi izraziti suburbanizaciji in terciarizaciji po letu 1991.

Zadnji sklop predstavljata poglavji Slovenski izobraževalni sistem in vloga izobraževanja učiteljev (KARMEN KOLENC KOLNIK) ter Sodelovanje slovenskih in nemških geografov (MIRKO PAK). V prvem prispevku je najprej na kratko predstavljen slovenski šolski sistem, nato pa položaj geografije kot učnega predmeta, ovrednoten z vidika sodobnih trendov razvoja splošnega izobraževanja in z vidika širše družbene 'uporabnosti' geografije. Prikaz glavnih faz in dosežkov sodelovanja med slovenskimi in nemškimi geografi opredeljuje v kontekstu dosedanjega razvoja medsebojnih odnosov tudi širše okoliščine nastanka in pomembnosti te monografije, kar predstavlja lep zaključek obsežne znanstvene monografije o Sloveniji.

Knjiga je lepo nadaljevanje dolgoletnega sodelovanja med slovenskimi in nemškimi geografi, ki se je začelo že v socialističnem obdobju nekdanje Jugoslavije in je med drugim v 60. letih prejšnjega stoletja obogatilo našo geografijo z idejami klimatske geomorfologije, pozneje pa je bilo zlasti uspešno na področju socialne geografije in didaktike geografije. Pričujoča knjiga bo nedvomno dosegla svoj namen v krogu bralstva, ki mu je prvenstveno namenjena (nemškim geografom in študentom geografije), vendar pa bi si zaradi moderne zasnove in kvalitetnih prispevkov zaslužila, da bi ji tudi slovenska država vsaj malo pomagala pri prodoru do širšega kroga uporabnikov, ki bi morali več vedeti o naši državi. In nenazadnje, zelo koristna bi bila tudi v slovenskem prevodu za naše domače bralce, saj smo poskušali, ob podpori nemškega sourednika, pogledati na Slovenijo nekoliko od strani in z malo širšega zornega kota....

Karel Natek 